\title{
Matrizes da linguagem e a organização virtual do conhecimento
}

\author{
Joel Gomes de Abreu \\ Bilbiotecário pela Universidade Estadual de Londrina. \\ E-mail: abreujg@hotmail.com
}

\section{Silvana Drumond Monteiro}

Universidade Estadual de Londrina, Centro de Educação Comunicação e Artes. Doutora em comunicação e semiótica pela Pontifícia Universidade Católica de São Paulo, PUC-SP, São Paulo, Brasil.

E-mail:drumond@sercomtel.com.br

\section{Resumo}

Os signos e as linguagens foram investigados para a organização virtual do conhecimento por meio dos mecanismos de busca. Fundamentou-se na teoria das matrizes da linguagem-pensamento, postuladas por Santaella (2005), na qual se perscrutou as linguagens sonora, visual e verbal. O objetivo da investigação foi estabelecer uma categorização dos mecanismos de busca a partir da correspondência dessas matrizes da linguagem com a indexação virtual e o modus análogo de busca. Os resultados da investigação indicam ser adequada a categorização dos mecanismos de busca sob o critério dos paradigmas semiótico da linguagem em três matrizes, dado o seu modo de ser e sua operacionalidade, sendo eles baseados em conteúdos sonoros, visuais e verbais. Sinteticamente, a sintaxe é a representação do sonoro, a forma é a representação do visível e o discurso é a representação do conhecimento verbal.

\section{Palavras-chave}

Organização do conhecimento. Mecanismos de busca. Matrizes da linguagem.

\section{Matrices of language and the virtual organization of knowledge}

\author{
Abstract \\ The signs and languages were investigated for the virtual \\ organization of knowledge by search engines. The study \\ was based on the theory of the matrices of language
}

and of thought, postulated by Santaella (2005), in which the sonorous, visual and verbal language was extracted. The purpose of this investigation was to establish a categorization of search engines, from the matching of these matrices of language with the virtual indexation and analog modus of search. Research results indicate that the categorization of the search engines is appropriate under the discretion of the semiotic paradigm of language in three matrices, by its way of being and function, since they are sonorous, visual and verbal based-content. Briefly, the syntax is the representation of the sonorous, the shape is the representation of the visible and the discourse is the representation of the verbal knowledge.

\section{Keywords}

Knowledge organization. Search engines. Matrices of language.

\section{INTRODUÇÃO}

A partir da virtualização dos recursos informacionais, verifica-se uma multiplicidade de signos e de linguagens no ciberespaço, bem como a automação do tratamento da informação apresenta diferentes paradigmas na organização dos estoques informacionais. Entende-se, nesse contexto, os mecanismos de busca como uma forma de organização desses conteúdos no ciberespaço que, a exemplo da multiplicidade semiótica nesse ambiente, também vêm se diversificando e apresentando-se sob o paradigma das matrizes linguagem-pensamento.

Com base nas teorias das "matrizes da linguagem" (SANTAELLA, 2005) e das "múltiplas sintaxes de organização e busca do conhecimento no ciberespaço" (MONTEIRO, 2002), investigou-se o grau de correspondência entre os mecanismos de busca com as matrizes sonora, visual e verbal, como contribuição teórica para a área de estudos em organização da informação e do conhecimento operada por máquinas no ciberespaço. 
De acordo com Santaella (2005), toda a variedade e multiplicidade das formas de linguagens estão primordialmente sustentadas em três matrizes de linguagem-pensamento: a sonora, a visual e a verbal. E a partir dessas, todas as combinações e misturas são possíveis. Aliás, os mecanismos de busca operacionalizam regimes de signos muito complexos, sobre os quais se pretendeu aproximar da compreensão por meio da teoria das matrizes da linguagem-pensamento.

Complementando as ideias, entende-se que a organização das obras simbólicas operada por mecanismos de busca está virtualizada e apresenta, ainda, outras características, a saber: a conexão, a heterogeneidade, a multiplicidade, a a-significância e a cartografia, ou seja, conceitos deleuzianos do Rizoma (MONTEIRO, 2002; 2009).

A utilização do termo "mecanismos de busca" neste trabalho compreende toda a arquitetura de um search engine. Embora sejam variadas, as arquiteturas dos mecanismos de busca contemplam três etapas, que são a captura de conteúdo, a indexação e a busca (PAGE; BRIN, 1998).

Nesse contexto, a busca em si é aquela que põe em conexão usuário e máquina, na qual o usuário utilizase de uma interface que oferece uma caixa de entrada, query, para que o usuário apresente sua intenção de busca. É neste ponto que a multiplicidade e a heterogenidade de signos e de linguagens podem ser verificadas e refletem a sintaxe de indexação operada de acordo com os critérios estabelecidos pelos algoritmos de ordenação e apresentação dos resultados.

O objetivo da pesquisa foi verificar em que medida as matrizes da linguagem correspondem à indexação virtual dos estoques informacionais no ciberespaço, bem como seu modus análogo de busca, visando a consolidar uma categorização dos mecanismos de busca baseada na semiótica das matrizes da linguagem e contribuir para o desenvolvimento da Linha de Pesquisa em Representação e Organização do Conhecimento no Ciberespaço.
Os resultados corroboram a premissa de múltiplas sintaxes dos mecanismos de busca, de Monteiro (2002), posto que as características de heterogeneidade e multiplicidade, principalmente de signos e de linguagens no ciberespaço, apresentamse também na indexação e busca virtuais.

E, ainda, os resultados obtidos a partir dos dados analisados revelam ser adequada a criação de uma categorização dos mecanismos de busca apoiada nos paradigmas semióticos e da linguagem, de modo que, coerentemente às matrizes da linguagem estão operantes em mecanismos de busca três matrizes virtuais de organização e de busca da informação e do conhecimento no ciberespaço, quais sejam: a sonora, a visual e a verbal.

Dessas três matrizes da linguagem supõe-se que operam todas as hibridizações de signos e de linguagens, bem como de organização e de busca da informação e do conhecimento no ciberespaço.

\section{A FENOMENOLOGIA E A SEMIÓTICA}

Neste trabalho, optou-se pela utilização de teorias específicas, sendo a fenomenologia e a semiótica de tradição peirciana as bases conceituais para esta investigação. Com isso, faz-se necessária a introdução, ainda que breve, desses assuntos, para o entendimento da análise dos dados e dos resultados obtidos.

Para o filósofo Charles Sanders Peirce (1839-1914), o fundamento observacional é o primeiro grande trabalho que a filosofia (fenomenologia) deve realizar. Nesse passo, após debruçar-se sobre a experiência, ela mesma, Peirce concluiu que só há três elementos formais ou categorias universalmente presentes em todos os fenômenos (SANTAELLA, 1995).

A palavra fenômeno deriva de phaneron, ou seja, qualquer coisa que aparece de qualquer modo à mente, sendo que, na concepção de Peirce, os fenômenos não possuem nenhuma moldura preestabelecida, e ainda: 
[...] não se restringia a algo que podemos sentir, perceber, inferir, lembrar, ou a algo que podemos localizar na ordem espaço-temporal que o senso comum nos faz identificar como sendo o 'mundo real'. Fenômeno é qualquer coisa que aparece à mente, seja ela meramente sonhada, imaginada, concebida, vislumbrada, alucinada... Um devaneio, um cheiro, uma ideia geral e abstrata da ciência... Enfim, qualquer coisa. (SANTAELLA, 1995, p. 16).

$\mathrm{Na}$ filosofia de Peirce, todos os fenômenos apreendidos pela mente humana são reduzidos a três categorias lógicas, são elementos formais, filamentos mais gerais, abstratos e universais de todo o universo. De acordo com Santaella:

Essas categorias não podem ser confundidas com entidades puras. Há infinitas modalidades de categorias particulares que habitam todos os fenômenos. Essas, no entanto, são as mais elementares e universais, tão gerais que podem ser vistas mais como tons, humores ou finos esqueletos do pensamento do que como noções definitivas. São pontos para os quais todos os fenômenos tendem a convergir. (SANTAELLA, 1995, p. 17).

No percurso de desenvolvimento dos estudos de Peirce, foram aplicadas diferentes denominações para nomear as categorias, pois em cada campo ou fenômeno elas assumem naturezas variadas, porém o substrato lógico-formal das categorias se mantém sempre. Buscando diferenciar suas categorias e evitar o uso de termos filosoficamente carregados de sentido, Peirce utilizou termos esvaziados de qualquer conteúdo material, reduzindo-os à sua natureza puramente lógica, e denominou suas categorias universais como primeiridade (mônada), secundidade (relação diádica) e terceiridade (relação triádica) (SANTAELLA, 1995).

\section{Conforme Santaella:}

O primeiro está aliado às ideias de acaso, indeterminação, frescor, originalidade, espontaneidade, potencialidade, qualidade, presentidade, imediaticidade, mônada... O segundo às ideias de força bruta, ação-reação, conflito, aqui e agora, esforço e resistência, díada... O terceiro está ligado às ideias de generalidade, continuidade, crescimento, representação, mediação, tríada. (1995, p. 18).

Na primeira vez em que Peirce divulgou suas ideias, as categorias foram restringidas estritamente aos fenômenos mentais, sendo a obra intitulada "Sobre uma nova lista das categorias". Treze anos mais tarde, Peirce estendeu-as a todos os fenômenos da natureza e do universo, desta vez intitulando-as "Um, dois, três: categorias fundamentais do pensamento e da natureza." (SANTAELLA, 2005).

A terceira categoria fenomenológica é o "crescimento contínuo", autogeração, semiose infinita, mediação, ação de gerar outro signo, ou seja, um interpretante do primeiro já é signo. É nessa categoria que nasce a semiótica peirciana, os estudos semióticos e a classificação dos signos. Nesse ponto, Peirce amplia a noção de signo para aquém do signo genuíno (signo terceiro), e as categorias fenomenológicas são reintrojetadas dentro da semiótica (SANTAELLA, 1995).

Essa também pode ser entendida como uma teoria lógica do signo e ocupa posição especial na filosofia de Charles Sanders Peirce (1839-1914), pois o estudo sobre os signos nos mais variados campos do saber o levaram a compor sua tese anticartesiana de que todo pensamento se dá em signo e, principalmente, na continuidade do signo.

Nesse sentido, a tese de Peirce fundamentou sua teoria sígnica do conhecimento, de que todo pensamento é continuação de outro pensamento e que leva a outro. Esse processo é denominado autogeração ou semiose infinita (SANTAELLA, 1995).

A semiótica, também denominada teoria dos signos, é uma ciência dedicada ao estudo de toda e qualquer linguagem capaz de produzir sentido, significação e de comunicar. Já o signo:

[... intenta representar, em parte pelo menos, um objeto que é, portanto, num certo sentido, a causa 
ou determinante do signo, mesmo se o signo representar seu objeto falsamente. Mas dizer que ele representa seu objeto implica que ele afeta uma mente, de tal modo que, de certa maneira, determine naquela mente algo que é mediatamente devido ao objeto. Essa determinação da qual a causa imediata ou determinante é o signo, e da qual a causa mediata é o objeto, pode ser chamada o interpretante [...]. (PEIRCE apud SANTAELLA, 1983, p. 58).

Apesar de o signo ser o primeiro da tríade da teoria dos signos (signo, objeto e interpretante), é o objeto que determina o interpretante de modo mediato (ou seja, mediado pelo signo). Pois ocorre que na semiótica se atribui ao signo uma primazia lógica, pelo seu caráter vicário de representação.

A semiótica, como ciência humana, emergiu em diferentes pontos do mundo e se concretizou a partir do crescimento do uso de informação veiculada em códigos e em mensagens alavancadas pelo avanço técnico, científico e tecnológico. Nesse sentido, foi emergente a criação de uma ciência "[...] capaz de criar dispositivos de indagação e instrumentos metodológicos aptos a desvendar o universo multiforme e diversificado dos fenômenos de linguagem [...]." (SANTAELLA, 1983, p. 16).

Embora exista grande quantidade de signos, os principais e mais divulgados nas apresentações sobre semiótica são três e dizem respeito ao signo em relação ao seu objeto, sendo esses tipos de signos denominados ícones, índices e símbolos. No entanto, Peirce também investigou o signo na relação em si mesmo e o signo em relação ao seu interpretante e desenvolveu uma tipologia de signos que ficou muito conhecida e contempla sua tradição triádica (quadro 1).

QUADRO 1

Classificação dos signos

\begin{tabular}{|c|c|c|}
\hline $\begin{array}{l}\text { SIGNO } 1^{\circ} \\
\text { em si mesmo }\end{array}$ & $\begin{array}{l}\text { SIGNO } 2^{\circ} \\
\text { com seu objeto }\end{array}$ & $\begin{array}{l}\text { SIGNO } 3^{\circ} \\
\text { com seu interpretante }\end{array}$ \\
\hline $\begin{array}{l}1^{\circ} \text { QUALI-SIGNO } \\
\text { Qualidade } \\
\text { Possibilidade } \\
\text { Sentimento }\end{array}$ & $\begin{array}{l}\text { ÍCONE } \\
\text { Semelhança }\end{array}$ & $\begin{array}{l}\text { REMA } \\
\text { Associações de semelhança associadas na mente. } \\
\text { Termo: signo de uma qualidade }\end{array}$ \\
\hline $\begin{array}{l}2^{\circ} \text { SIN-SIGNO } \\
\text { Realidade } \\
\text { Atualidade } \\
\text { Existente } \\
\text { Sensação }\end{array}$ & $\begin{array}{l}\text { ÍNDICE } \\
\text { Conexão } \\
\text { Referência }\end{array}$ & $\begin{array}{l}\text { DICENTE } \\
\text { É pela existência que o interpretante confirma o } \\
\text { objeto. Ou a exposição de um contexto, fatos, } \\
\text { proposição. }\end{array}$ \\
\hline $\begin{array}{l}3^{\circ} \text { LEGI-SIGNO } \\
\text { Lei } \\
\text { Ideia } \\
\text { Lógica }\end{array}$ & $\begin{array}{l}\text { SÍMBOLO } \\
\text { Abstração } \\
\text { Representação } \\
\text { Hábito }\end{array}$ & $\begin{array}{l}\text { ARGUMENTO } \\
\text { Forma lógica } \\
\text { Dedução } \\
\text { Os signos de lei asseguram-se sua validade. }\end{array}$ \\
\hline
\end{tabular}


Quanto à tríade ícone, índice e símbolo, que é o signo em relação ao seu objeto, vale ressaltar que o ícone não representa apenas seus objetos por semelhança e isomorfismo, como nas percepções visuais: desenhos, imagens, pinturas e diagramas, mas também por percepções mentais e auditivas. Os ícones são tão abstratos que não representam mais que sentimentos e formas, pois a qualidade significante do ícone provém de suas qualidades (MONTEIRO, 2006).

Já o signo indicial está em conexão dinâmica com a realidade, por ora o que quer que seja "real", e envolve a existência de seu objeto. $\mathrm{O}$ índice é um signo segundo e se a secundidade for uma existência de fato, o índice é genuíno, se a secundidade for uma referência, então o índice é degenerado.

Quanto ao signo simbólico, suas características principais são a generalidade da lei, a regra, o hábito ou a convenção da qual o signo símbolo é associado. E sua função como signo dependerá dessa força viva que governará e determinará seu interpretante.

No âmbito deste trabalho, o signo é sempre um existente, um registro fixado em qualquer suporte digital e acessível virtualmente por meio dos programas de computador e das conexões no ciberespaço.

Nesse sentido, o ícone puro e enquanto mera qualidade de sentimento, ou pura qualidade, se perde no momento mesmo do registro ou fixação do signo em qualquer tipo de suporte. Vale notar que, no interior da semiótica, opera a lógica da recursividade e em cada nível ou campo fenomênico as categorias são reintrojetadas.

\section{MATRIZES DA L I N G UAGEM - PENSAMENTO}

A teoria das matrizes da linguagem-pensamento, a sonora, a visual e a verbal, foi postulada por Santaella (2005), que se baseia fundamentalmente nas categorias universais da fenomenologia peirciana e na classificação dos signos em uma perspectiva semiótica. Também é importante salientar que no interior das matrizes opera a lógica recursiva, ou seja, nota-se que são observados em cada uma das matrizes os caracteres de cada uma das categorias fenomenológicas e da classificação dos signos. Os aspectos da linguagem sonora são identificáveis na linguagem visual e as características de ambas aparecem na linguagem verbal.

De acordo com Santaella (2005), a matriz sonora está para a primeiridade e é uma questão do ícone, a matriz visual está para a secundidade e é uma questão do índice, e a matriz verbal está para a terceiridade e é uma questão do símbolo. Assim, para compor o diagrama das matrizes foram fixados três eixos classificatórios, de modo que o eixo da sintaxe está para a matriz sonora, o eixo da forma está para a matriz visual e o eixo do discurso está para a matriz verbal (SANTAELLA, 2005).

Mas dizer que a matriz sonora está para a primeiridade não a impede de expandir-se para os domínios da secundidade e da terceiridade, pois essas são reintrojetadas no interior dessa matriz. O mesmo pode-se dizer sobre a matriz visual que estende para o domínio icônico e simbólico as investigações das formas visuais. Do mesmo modo, pode-se dizer que também a matriz verbal apresenta no seu interior correspondências com os caracteres icônicos e indiciais. Por exemplo, o caso dos adjetivos e dos discursos descritivos, proeminentemente icônicos, e o caso dos pronomes, por exemplo 'este', 'aquele', que mantêm relações existenciais com seus objetos e também é o caso das narrativas.

Com base nessas orientações para o estudo das linguagens, Santaella elaborou um diagrama (diagrama 1) que compreende 27 modalidades dentro de cada matriz (aqui explicitadas 9, no interior delas). Estas estão distribuídas nas três matrizes primordiais - a sonora, a visual e a verbal. Em cada nível são introjetadas as categorias fenomenológicas e se investigam seus caracteres correspondentes no diagrama das matrizes. 
DIAGRAMA 1

As três matrizes e suas modalidades

\begin{tabular}{|c|c|c|}
\hline $\begin{array}{l}\text { 1. Matrizes sonora } \\
\text { 1.1 Sintaxes do acaso } \\
\text { 1.1.1 Puro jogo do acaso } \\
\text { 1.1.2 Acaso como busca } \\
\text { 1.1.3 Modelizações do acaso }\end{array}$ & & \\
\hline $\begin{array}{l}\text { 1.2 Sintaxe dos corpos sonoros } \\
\text { 1.2.1 Heurística dos corpos } \\
\text { 1.2.2 Dinâmica das gestualidades } \\
\text { 1.2.3 Som e abstrações }\end{array}$ & $\begin{array}{l}\text { 2. Matriz visual } \\
\text { 2.1 Formas não representativas } \\
\text { 2.1.1 Talidade } \\
\text { 2.1.2 Marca do gesto } \\
\text { 2.1.3 Invariância }\end{array}$ & \\
\hline $\begin{array}{l}\text { 1.3 Sintaxes convencionais } \\
\text { 1.3.1 Ritmo } \\
\text { 1.3.2 Melodia } \\
\text { 1.3.3 Harmonia }\end{array}$ & $\begin{array}{l}\text { 2.2 Formas figurativas } \\
\text { 2.2.1 Sui generis } \\
\text { 2.2.2 Conexão dinâmica } \\
\text { 2.2.3 Codificação }\end{array}$ & $\begin{array}{l}\text { 3. Matriz verbal } \\
\text { 3.1 Descrição } \\
\text { 3.1.1 Qualidade } \\
\text { 3.1.2 Indicial } \\
\text { 3.1.3 Conceitual }\end{array}$ \\
\hline & $\begin{array}{l}\text { 2.3 Formas representativas } \\
\text { 2.3.1 Semelhança } \\
\text { 2.3.2 Cifra } \\
\text { 2.3.3 Sistema }\end{array}$ & $\begin{array}{l}\text { 3.2 Narração } \\
\text { 3.2.1 Espacial } \\
\text { 3.2.2 Sucessiva } \\
\text { 3.2.3 Causal }\end{array}$ \\
\hline & & $\begin{array}{l}\text { 3.3 Dissertação } \\
\text { 3.3.1 Conjectural } \\
\text { 3.3.2 Relacional } \\
\text { 3.3.3 Argumentativa }\end{array}$ \\
\hline
\end{tabular}

Fonte: Santaella, 2005, p. 372. 


\section{METODOLOGIA}

O enfoque deste trabalho foi o de uma pesquisa teórico-formal e multidisciplinar, posto que fundamenta-se fortemente na semiótica peirciana, passando pela informática para perscrutar e construir, por meio da análise de um corpus, o objeto na ciência da informação. A pesquisa documental, como delineamento, diferentemente das pesquisas sociais em que se estudam os sujeitos, opera a investigação baseada em documentos, que podem ser coletados em diversas fontes e formatos.

Vale ressaltar que o objeto específico é sempre o conteúdo do conceito que exprime as propriedades ou atributos que definem o conceito e, portanto, o próprio objeto. Assim, o objeto específico, isto é, aquele que será construído no decorrer da pesquisa, pode ser considerado real, posto que é existente, mas abstrato, uma vez que é simbólico, isto é, constructo elaborado por uma sociedade em determinado momento tecnológico.

Para Alves (2003, p. 308), a melhor maneira de conhecer os objetos culturais (leia-se simbólicos), isto é, os objetos humanos, é a compreensão, já que "a ação humana comporta ser compreendida segundo nexos de finalidade e não de causalidade". As relações de causalidade fazem parte da análise dos componentes de objetos reais naturais, em que a explicação dos fenômenos faz-se quer pela referência de um fenômeno como causa de outro, quer pela diluição em seus elementos pela análise. Assim, a explicação é a forma mais apropriada para a cognição dos objetos da natureza, e a compreensão para a cognição dos objetos culturais.

$\mathrm{Na}$ ciência da informação a análise documental (como método) pode e deve utilizar-se do corpus de pesquisa, ou seja, de uma amostra de documentos ou fontes selecionadas a priori, ou a posteriori, para o desenvolvimento do estudo. Assim, quando a coleta de dados é realizada na linguagem e documentos, configura-se o corpus, em vez do sujeito de pesquisa, próprio das investigações inseridas no contexto metodológico das ciências sociais.
Para Bardin (1977, p.96), "o corpus é o conjunto de documentos tidos em conta para serem submetidos aos procedimentos analíticos. A sua constituição implica escolhas, seleções e regras". Para Barthes (1997, p. 104), "o corpus é uma coleção finita de materiais, determinada de antemão pelo analista, conforme certa arbitrariedade (inevitável) em torno da qual ele vai trabalhar".

Nesse sentido, utilizou-se a pesquisa documental para o levantamento do corpus com o qual se desenvolveu a investigação (base empírica da investigação), por meio da análise documental, para comprovação dos pressupostos teóricos com sua correspondência operacional no ciberespaço.

Neste trabalho, entende-se por mecanismos de busca os programas de computador utilizados para indexação e busca dos recursos informacionais e de conhecimento no ciberespaço. Em inglês o termo aplicado é search engine.

Quanto à indexação, entende-se por indexação maquinica os índices gerados automaticamente pelos mecanismos de busca (índice invertido) e recuperáveis por meio da interface de busca que apresenta o índice de tempo de execução de acordo com a solicitação apresentada pelo usuário. Do ponto de vista filosófico, significa uma ruptura com a indexação manual. Conceitos situados na pós-modernidade explicam a indexação operada pelas máquinas, programas de computador (MONTEIRO; ABREU, 2009). Em certos momentos, também utiliza-se a expressão indexação virtual, indicando a operação de programas de computador na indexação.

Assim, para efeito do objetivo de "Categorizar os mecanismos de busca a partir de sua correspondência com a fenomenologia e a semiótica das matrizes da linguagem", foi selecionado um corpus para investigar os mecanismos de busca sonoros, visuais e verbais, de acordo com os seguintes eixos de análise:

a) indexação e busca dos documentos musicais versus matriz sonora, eixo da sintaxe; 
b) indexação e busca dos documentos visuais versus matriz visual, eixo da forma;

c) indexação e busca baseadas em texto versus matriz verbal, eixo do discurso.

Portanto, este trabalho teve em sua análise documental a investigação dos mecanismos específicos, sendo o Musipedia (paradigma sonoro), Retrievr, Vizseek, Google Earth (paradigma visual) e Buscapé, Google Blog e Google Scholar (paradigma verbal) escolhidos para comprovar (ou não) as premissas sobre as matrizes da linguagem nos mecanismos de busca e assim autorizar (ou descartar) a categorização dos mecanismos de busca sob o critério dos paradigmas semióticos. Esses mecanismos de busca estão explicitados no quadro 2 .

Neses mecanismos de busca foram analisadas suas operacionalidades com relação à semiótica das matrizes da linguagem-pensamento, matrizes sonora, visual e verbal. Por exemplo, tendo como partida o signo sonoro para a busca, pode-se deduzir que o item indexado é uma representação sonora e está no lugar lógico de um recurso sonoro, e que demonstra uma cadeia lógica de representação. Esta lógica de representação está presente em todas as matrizes, sejam elas sonoras, visuais ou verbais.

\section{RESULTADOS E DISCUSSÃO DO CORPUS DE PESQUISA}

Embora se tenha escolhido apenas um exemplar para o paradigma sonoro, ele supre as necessidades de um corpus que viabilizasse a investigação e que correspondesse aos aspectos organizacionais da linguagem sonora. Quanto à escolha de um número maior de exemplares nos paradigmas visual e verbal, não se pretendeu explicitar subcategorias especificamente, mas que, segundo à abordagem deste trabalho, realçam diferentes aspectos das diversas modalidades e submodalidades apresentadas por Santaella (2005) nas matrizes visual e verbal.

\section{Paradigma sonoro dos mecanismos de busca}

Iniciando a análise dos mecanismos sonoros, do ponto de vista tecnológico, o método de indexação de conteúdos de áudio também pode ser denominado técnicas extração, que, por sua vez, extraem e determinam as características e variâncias que tipificam o áudio para serem descritas em representações sonoras condensadas da música.

QUADRO 2

Corpus de pesquisa

Paradigma sonoro de indexação e busca

\begin{tabular}{l|l}
\hline Musipedia & http://www.musipedia.org/
\end{tabular}

Paradigma visual de indexação e busca

\begin{tabular}{l|l}
\hline Retrievr & http://labs.systemone.at/retrievr/ \\
\hline Vizseek & http://www.vizseek.com/ \\
\hline GoogleEarth & é preciso baixar o programa \\
\hline
\end{tabular}

\section{Paradigma verbal de indexação e busca}

\begin{tabular}{l|l}
\hline Buscapé & $<$ www.buscape.com.br $>$ \\
\hline Google Blog & $<$ http://blogsearch.google.com.br $>$ \\
\hline Google Scholar & $<$ http://scholar.google.com.br $>$ \\
\hline
\end{tabular}


Essas representações podem ser arquivos MIDI (Musical Instrument Digital Interface) e CMN (Common Music Notation).

A extração do tema e a classificação dos itens no índice utilizam esses parâmetros para identificar diferenças sutis entre os recursos analisados e sistematizá-los, proporcionando velocidade na busca. Contudo, a busca por conteúdos musicais pode ser executada por meio de outra metodologia de busca em áudio denominada transcrição. Essa técnica converte uma expressão de busca em uma representação que viabiliza a busca em bases de dados de áudio completo, por exemplo, composta por arquivos WAV e MP3, e/ou em índices de conteúdo musical, porém essa abordagem exige mais tempo para responder a uma consulta do usuário (REISS; SANDLER, 2002).

No ciberespaço, elegeu-se o domínio de busca Musipedia como corpus para a investigação desses mecanismos que operam a indexação e a busca baseadas em conteúdos sonoros e musicais (figura 1). Esse, embora seja semelhante quanto ao aspecto colaborativo dos usuários na construção e na edição dos conteúdos da base de dados, não é afiliado à Wikipédia.

O conteúdo da coleção na base de dados compõe-se de melodias e temas musicais, e a base foi planejada para ser pesquisável, editável e expandível. O Musipedia é uma iniciativa de Rainer Typk, mas é mantido por muitos outros colaboradores para idealizar a logomarca, planejar a interface, traduções para outras línguas, novos implementos para o sítio, e os próprios usuários são editores dos registros da base.

Esses registros podem conter um pedaço da faixa da música, um arquivo MIDI, a informação textual sobre a obra e o seu compositor, e por último, mas não menos importante, o código

\section{FIGURA 1}

\section{The Musipedia: melody search engine}

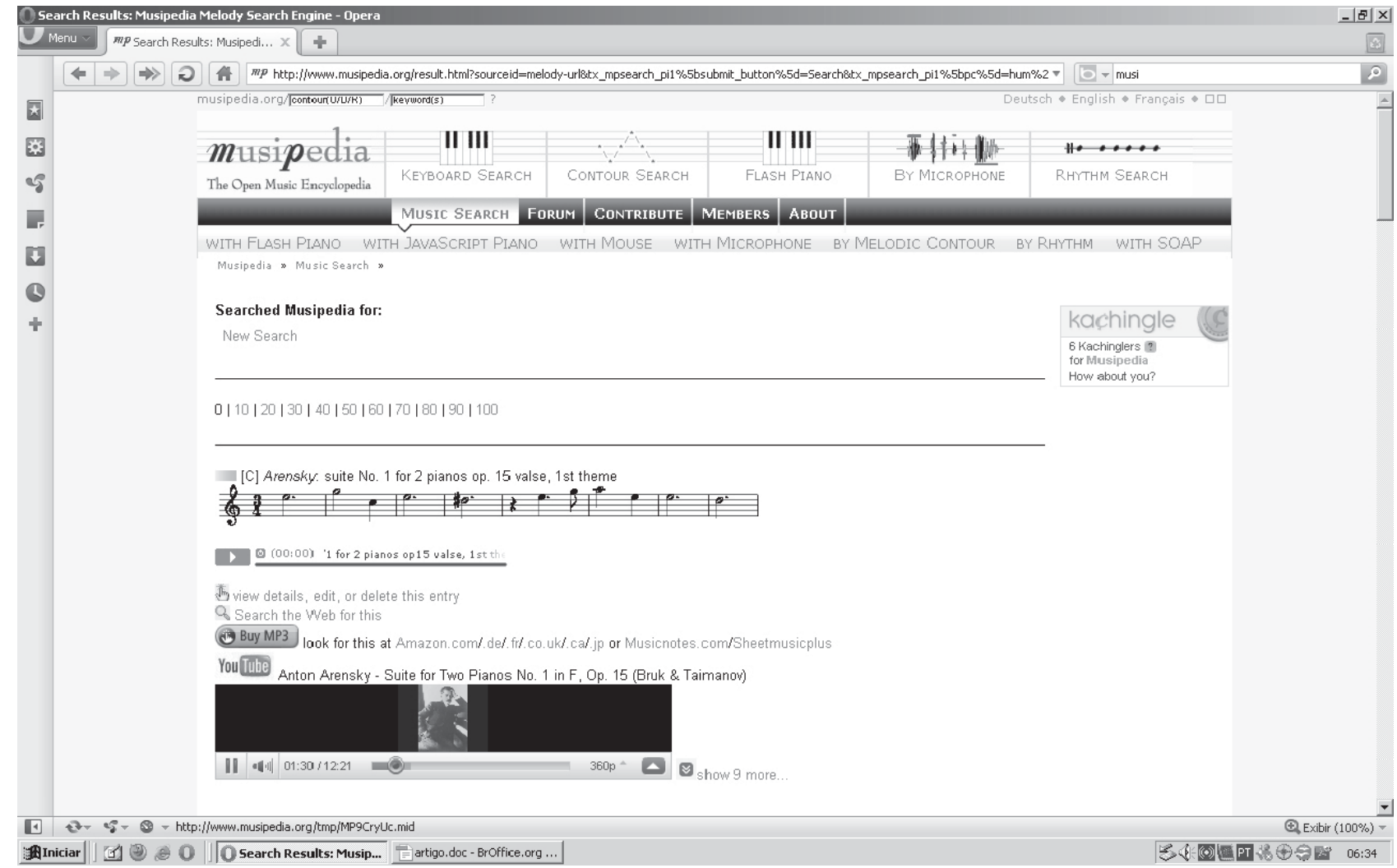


de Parson, que representa o contorno melódico contido no documento.

Esse mecanismo aceita buscas com base no ritmo, em que o usuário pode expressar sua intenção batendo ritmicamente no teclado da máquina, e também opera com a inserção direta de som, seja a voz do usuário cantando um trecho da música, ou tocando algum instrumento musical perante um microfone conectado em uma máquina com acesso em rede. Nesse caso, é necessário um mínimo de tempo de gravação, por exemplo, 10 segundos de gravação seriam necessários para extrair padrões como notas, tons e qualificar a expressão de busca em uma representação sonora e musical para compará-la aos documentos contidos nos índices ou base de dados de conteúdos completos.

Quanto ao aspecto da linguagem sonora e sua correspondência aos mecanismos de busca da música, salienta-se que o fato de a linguagem sonora estar contemplada na categoria fenomenológica de primeiridade e de domínio semioticamente icônico apresenta certa complexidade para seu entendimento e uso, pois os ícones apenas podem apresentar qualidades, possibilidades e sugestões.

Outro aspecto que se detectou nesta investigação é o fato de que, do ponto de vista semiótico, faz-se imprescindível que o usuário de busca detenha certo conhecimento da organização da linguagem sonora, níveis que se aproximam do legi-signo, para interagir de acordo com regras, leis e convenções desse regime semiótico, ou seja, o usuário precisa ter hábito, no sentido peirciano, para lidar proveitosamente com esses mecanismos.

Tanto é assim que a indexação maquínica da música parece agregar conhecimentos comuns aos estudos semióticos da linguagem sonora, tais como os apresentados na modalidade sintaxes convencionais, ou seja, o ritmo, a melodia e a harmonia. Entretanto, é certo que outros componentes do som, como altura, duração, intensidade e timbre são também contemplados tanto nas investigações semióticas da matriz da linguagem sonora, quanto nos estudos sobre a indexação e busca maquínicas da música, ou seja, aquela operada pelos mecanismos de busca.

A linguagem sonora é ainda domínio do acaso a mais livre; a recepção do som emitido por um usuário no ato da busca pode ser interferida por outros sons do ambiente natural no percurso para o ambiente digital da máquina. Esse aspecto é enfatizado tanto em relação aos mecanismos de busca sonoros e musicais no tratamento de ruídos, quanto nos estudos da matriz sonora. De acordo com Santaella (2005), na modalidade dinâmica das gestualidades, especificamente na submodalidade $a$ gestualidade sonora no espaço externo, a sintaxe sonora se hibridiza com o ambiente arquitetônico. De modo correlato, os mecanismos de gravação e de tratamento da expressão da busca também se situam nessa problemática.

Embora outros aspectos também possam ser correspondidos entre a matriz sonora e a operacionalização da organização virtual da linguagem sonoro no ciberespaço, a partir dos mecanismos de busca, o que se pretendeu argumentar foi a correspondência do eixo da sintaxe na matriz sonora para o estudo da organização virtual dos conteúdos sonoros em bibliotecas digitais virtuais e mecanismos de busca.

Nesse sentido, salienta-se que o principal elemento na sintaxe sonora é o tempo, de modo que, se há tempo na música, há também uma sintaxe, ou seja, um modo de organização ou regra em que os eventos sonoros ocorrem no tempo, uma ordem de repetição que engendra uma gramática própria.

Portanto, argumenta-se que os mecanismos de busca sonoros, de modo semelhante à matriz sonora, extraem do tempo os acontecimentos sonoros para sua tipificação, representação e organização. Tanto é assim que o ritmo se desenvolve no tempo, a melodia é a diferenciação das alturas das notas musicais no tempo, e a harmonia é a ocorrência simultânea de diferentes notas musicais em um percurso temporal. 


\section{Paradigma visual dos mecanismos de busca}

No caso da linguagem visual, do ponto de vista tecnológico, a indexação maquínica de imagens está baseada em operações de extração e análise de atributos próprios das formas visuais. No contexto das tecnologias da informação podem ser fotos digitais, imagens digitalizadas, imagens gráficas criadas diretamente em programa de edição de imagens (tais como caricaturas, desenhos gráficos, logomarcas etc.), fotos digitais de satélites, imagens médicas digitalizadas, imagens de assinaturas digitais e biomédicas.

$\mathrm{Na}$ literatura encontram-se algumas definições diferentes para referir-se a esse campo de estudo, tais como Content-Based Image Retrieval (CBIR), Query By Image Content (QBIC), em menos frequência como Content-Based Visual Information Retrieval (CBVIR) e os aspectos comumente abordados são a cor, a textura, a forma e a espacialidade (IDRIS; PANCHANATHAN, 1997 apud GOODRUM, 2000).

\section{FIGURA 2}

\section{Retrievr: search by sketch / search by image}

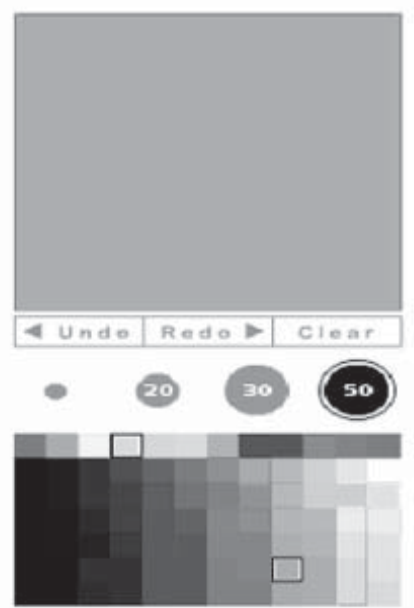

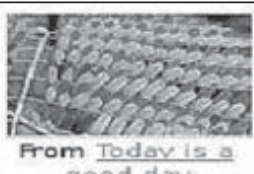
good day

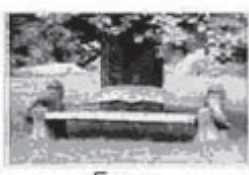

From SERENDIPIT $\cdots$
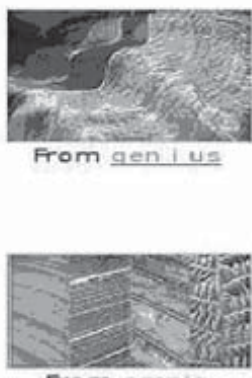

from omnia
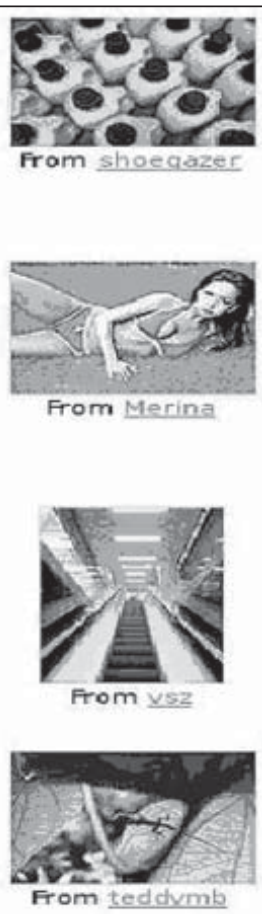

From Merina
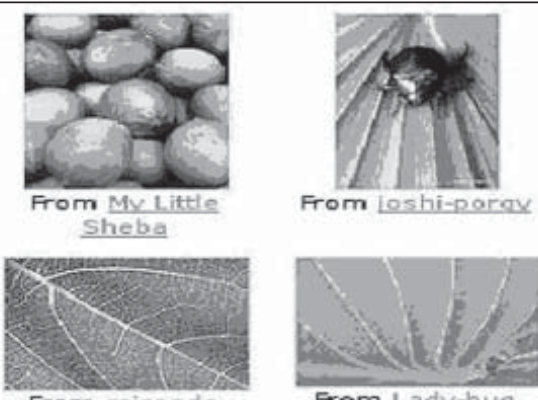

From mirande
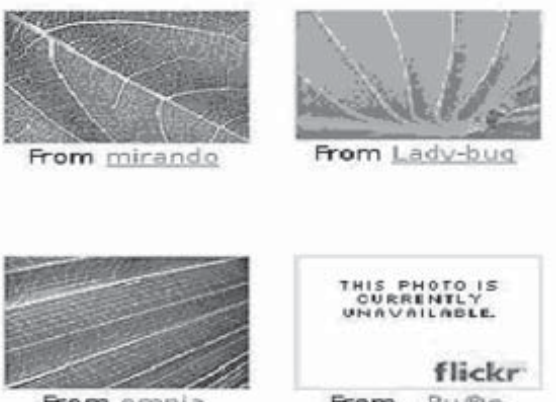

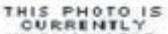
Langreiter Christian e aplicado em 2006 para indexar e buscar na base de dados de fotos Flickr do Yahoo! Segundo seu criador, não é uma ferramenta eficiente de busca, mas uma maneira criativa e divertida de explorar coleções de fotos. Para utilizar o mecanismo de busca Retrievr é oferecida uma caixa de busca simples e em branco, também sendo ofertadas quatro opções de tamanho de pincel e um espectro de onze cores, a partir dos quais o mecanismo de busca baseia-se nas expressões visuais feitas pelo usuário para retornar recursos visuais que mais ou menos combinam ou se aproximam da sua intenção

No Retrievr destaca-se a proeminência de aspectos fenomenológicos de primeiridade, ou seja, características dos recursos visuais que se aproximam das formas não representativas descritas na matriz visual, formas que nada representam, apenas apresentam-se, como, por exemplo, as cores. As cores são altamente sugestivas e ambíguas, dizem apenas sobre atributos
formas visuais, isto é, pura possibilidade. 
Nota-se que, semioticamente, a cor é mera possibilidade e pode encarnar em diversas formas; a cor é pura qualidade, mas quando materializada em um corpo é atributo desse corpo e, por isso, pode ser denominada um sin-signo icônico. Os resultados assemelham-se à expressão de busca pela qualidade, que no exemplo anterior refere-se à qualidade de verde, contudo os resultados são ambíguos e sugestivos. Esse mecanismo também considera o volume de coloração, no exemplo citado, com muito verde, mas também operacionaliza a localização da cor pela espacialidade nas formas visuais.

Todavia, as formas visuais também assumem níveis representativos e os exemplos mais apropriados podem ser extraídos das formas figurativas. Pois a forma, nesse caso específico, se entendida gestalticamente, apresenta o binômio figura-fundo. A figura, nesse caso, é uma forma organizada, que possui contornos e se diferencia por intensidade do fundo que é amorfo, indefinido e inorgânico.

De acordo com Santaella (2005), as formas figurativas em nível de primeiridade estão relacionadas à qualidade, ou seja, à figura sui generis, e nesse caso, o usuário recria qualquer objeto, mas atribuindo a ele uma realidade plástica. No nível de leis que governam a ocorrência dos signos, a autora cita os esteriótipos que, por mais estilizados e singulares que possam ser, sempre apresentam algum traço relacionado ao objeto que referenciam. São exemplos os desenhos de castelos, de coqueiros, mas também podemos dizer de bonés, de camisas, de parafusos e de aparatos técnico-industriais.

No ciberespaço, elegeu-se o mecanismo de busca VizSeek, desenvolvido pela empresa VizSpace \& HotSpot, que busca recursos visuais de desenhos industriais elaborados bi e tridimensionalmente (figura 3).

Nesse mecanismo, o atributo principal para relevância dos resultados é a forma. Nele também se oferecem recursos próprios das formas visuais para elaboração da expressão de busca, tais como círculos, quadros, retângulos, triângulos, linhas retas e curvas e ferramentas de desenho a mão livre.

Quanto à correspondência da operacionalização dos signos visuais nesse mecanismo específico e a matriz visual, é relevante o aspecto mimético das formas figurativas, do qual se pode descrever uma cadeia de relações semióticas. A forma feita pelo usuário imita o objeto na base de dados, que imita,

VizSeek: powerful shape search and ontology engine
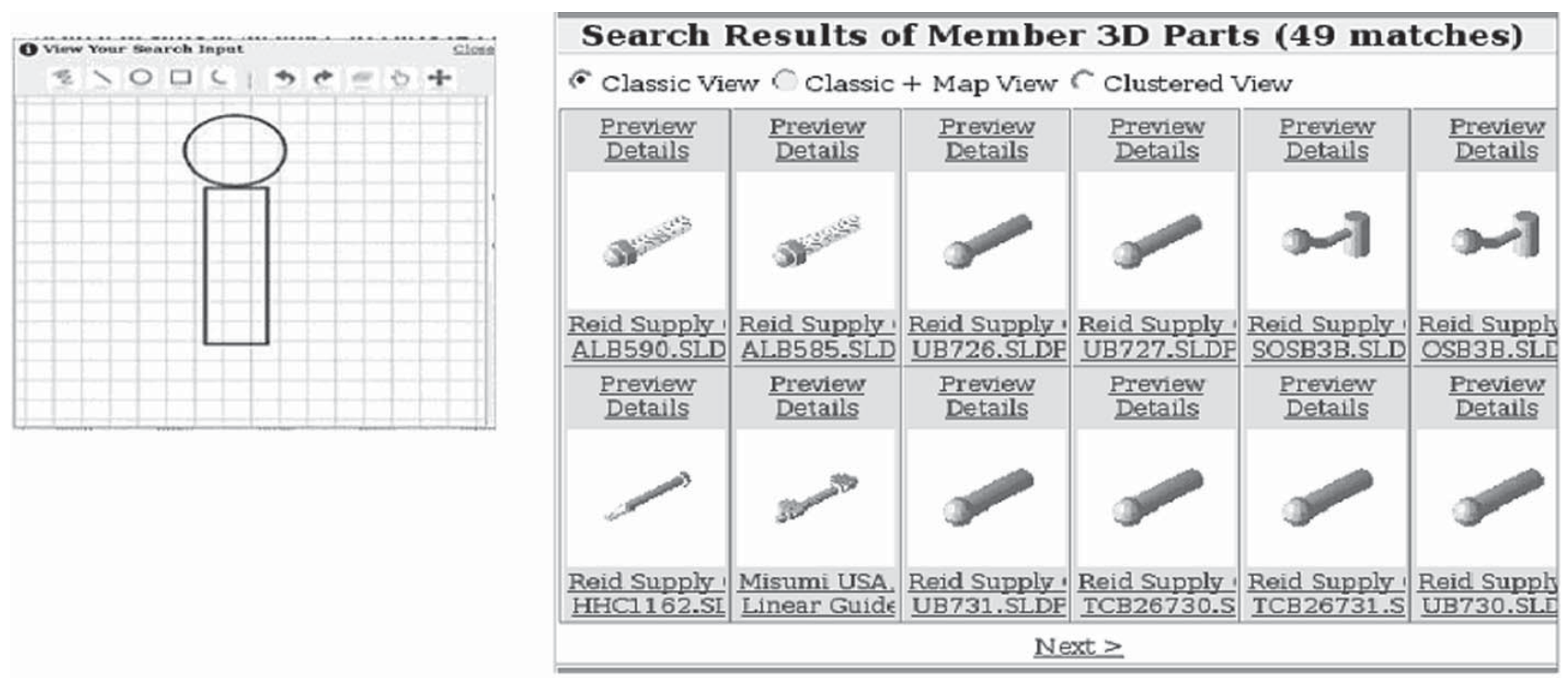
por sua vez, o objeto referenciado. O signo, nesse caso, está sendo determinado pelo objeto dinâmico da realidade, aquele produto industrial no mundo externo que consta também no catálogo de vendas das empresas fornecedoras no mundo real.

A seguir, analisa-se o domínio de busca geoespacial Google Earth (figura 4).

Quanto ao aspecto da linguagem, embora seja possível utilizar palavras para localizar algum ponto específico no espaço geográfico, pode-se dizer também que essas palavras operam semioticamente como índices, domínio da categoria fenomenológica de secundidade. Esse programa específico utiliza predominantemente fotos de satélites, portanto, são programas dominantemente visuais. E essas formas de representação visual correspondem perfeitamente à modalidade da figura como registro.

Em relação aos mapas, embora sejam também imitativos, e ainda, indiciais, a proeminência da ação sígnica dos mapas recai sobre as convenções pelas quais eles são governados. É certo que as imagens georreferenciais são registros físicos que mantêm conexão dinâmica com seus objetos, são diádicas, mas principalmente com respeito aos mapas, o que vale são os tratados e convenções fronteiriças.

Por isso, pode-se dizer que os mecanismos de busca geográficos são proeminentemente visuais porque lidam com formas de representações visuais, mas as leis que governam as fronteiras são especialmente, em nível fenomenológico, de terceiridade, e correspondem semioticamente aos legi-signos, ou seja, nível de convenções e hábitos que governam a ação dos signos.

Outro ponto relevante, que corresponde à preponderância visual dos mecanismos de busca geoespaciais, é a possibilidade de navegação tridimensional em alguns locais que indicam o mundo real, ou

\section{FIGURA 4 \\ Google Earth}

seja, navegação em centros urbanos globais de forma totalmente simulada no programa em tela.

No caso da linguagem visual, situada no nível de secundidade (índice), a relação de existência e presentidade parece, hipoteticamente, diminuir a complexidade de busca, pois o usuário se depara com os recursos de desenho e coloração utilizados para buscar conteúdos visuais. A forma dos desenhos bi e tridimensionais, seus atributos, como a coloração, a posição e a figura são o que parecem operar a lógica da indexação e da busca nesses mecanismos baseados em conteúdos visuais.

\section{Paradigma verbal dos mecanismos de busca}

Quanto à linguagem verbal, os mecanismos de busca apresentam a maior audiência para captar todo tipo de conteúdo. Bem mais conhecidos como mecanismos de busca textual (linguagem verbal escrita), esses buscadores parecem apresentar o menor grau de complexidade para utilização dos usuários. Talvez isso se deva ao hábito que a maioria dos usuários tenha com os signos simbólicos, bem como à convencionalidade de seus empregos e usos. Fenomenologicamente, esses mecanismos estão em relação à categoria de terceiridade e os caracteres dessa categoria são a representação, a generalidade, a mediação, lei ou regra.

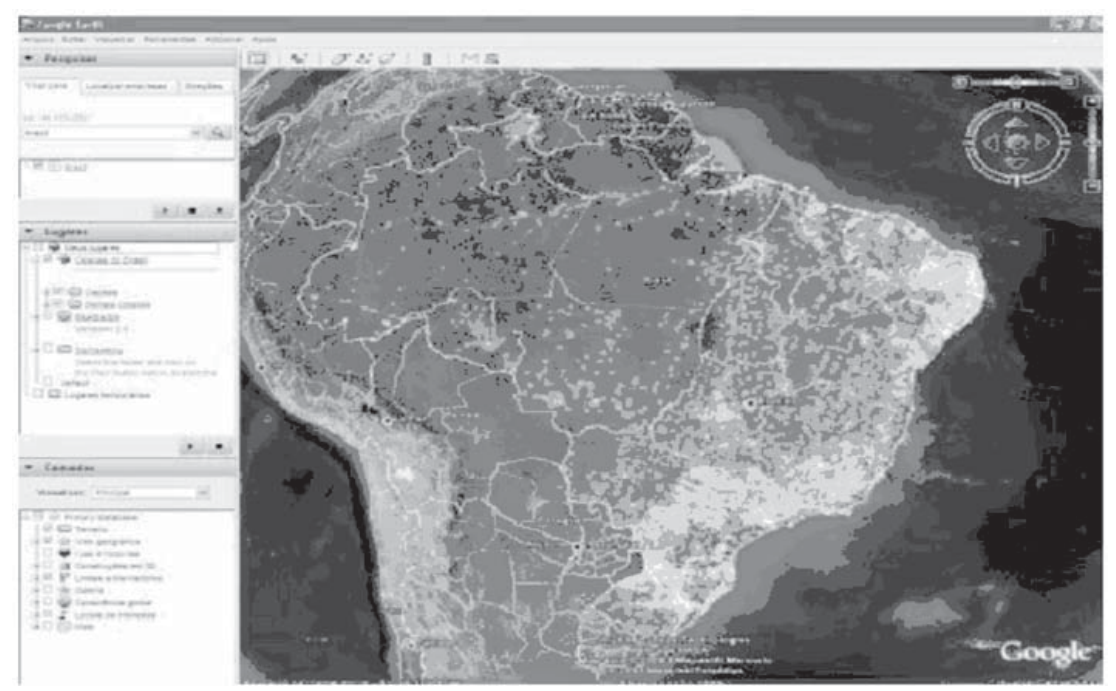


Para Santaella (2005), a matriz verbal tem seu eixo classificatório no discurso. Com efeito, são a descrição, a narração e a dissertação as três modalidades ou princípios organizadores da sequencialidade discursiva. Nesse seguimento é o sistema de símbolos que tem função representativa, já que as palavras estão ligadas simbolicamente aos seus objetos. Mas "não se trata, portanto, de uma taxonomia fixa, mas de focos de inteligibilidade para os modos analógicos, existenciais e lógicos através dos quais o discurso escrito realiza as suas armações." (SANTAELLA, 2005, p. 367).

É curioso observar que os mecanismos de busca que operam os signos verbais, embora de outra complexidade, estão sendo pensados a partir dos estudos do discurso, quer sejam ontologias, lógicas discursivas, semânticas, hermenêuticas, entre outras.

Outra observação é importante: todas as palavras/termos/ conceitos utilizados para a busca são considerados parte do todo, metonímias, ligações conceituais para os discursos de informação e de conhecimento no ciberespaço que, logicamente, representam e estão ligados a um corpus de conhecimento.

A lei de representação, contida no signo simbólico, faz com que esse signo gere outro signo a ser interpretado, de modo que de palavras isoladas passamos para as proposições, destas para os discursos. Da mesma forma ocorre com os buscadores, no continuum das ligações de contexto.

Logo, no nível de primeiridade, a linguagem descritiva representa uma tentativa de traduzir, por meio do verbal, o mundo de qualidades dos objetos. Assim é que, em razão de os mecanismos de busca operarem

FIGURA 5

FIGURA 6 na linguagem natural, termos qualitativos podem ser argumentos de busca em sities em geral, em especial, uma modalidade de buscadores, como os especializados em compras, como o Buscapé (figura 5) e seus similares nacionais e internacionais.

Qualidades e especificações de produtos, descrição de preços e tags associadas fazem parte do repertório descritivo de seus objetos. Nessa categoria, pode-se ilustrar também o mecanismo A9 da Amazon (figura 6), que opera similarmente em seu acervo de livros.

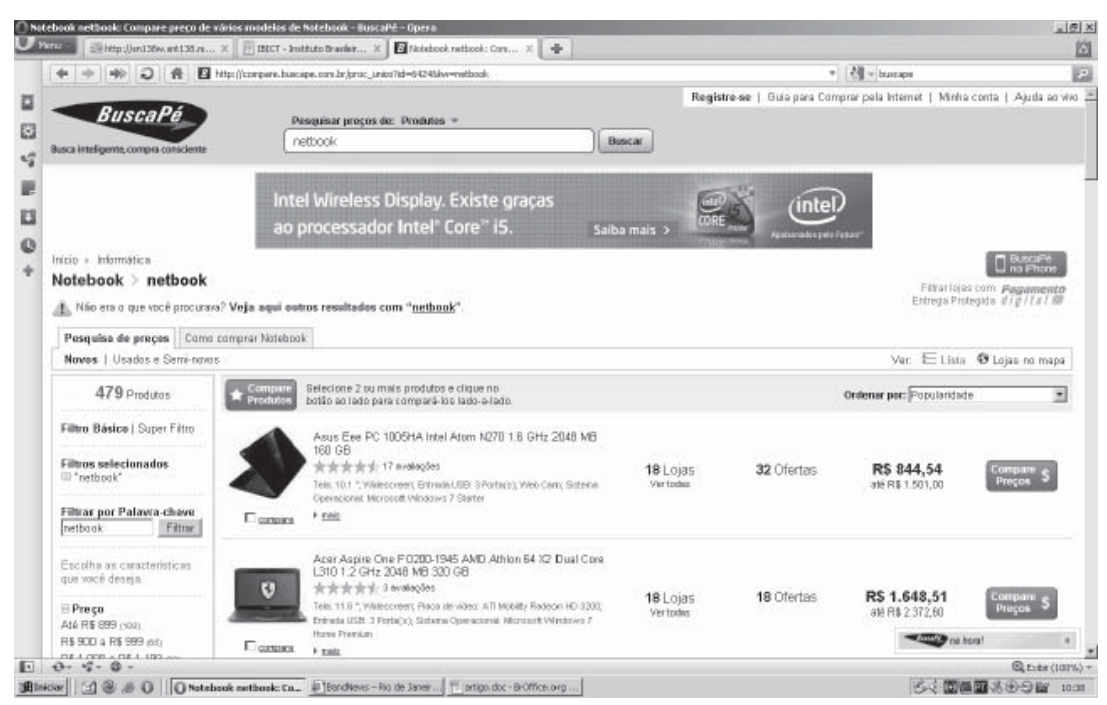

A9.com: Innovations in search technologies

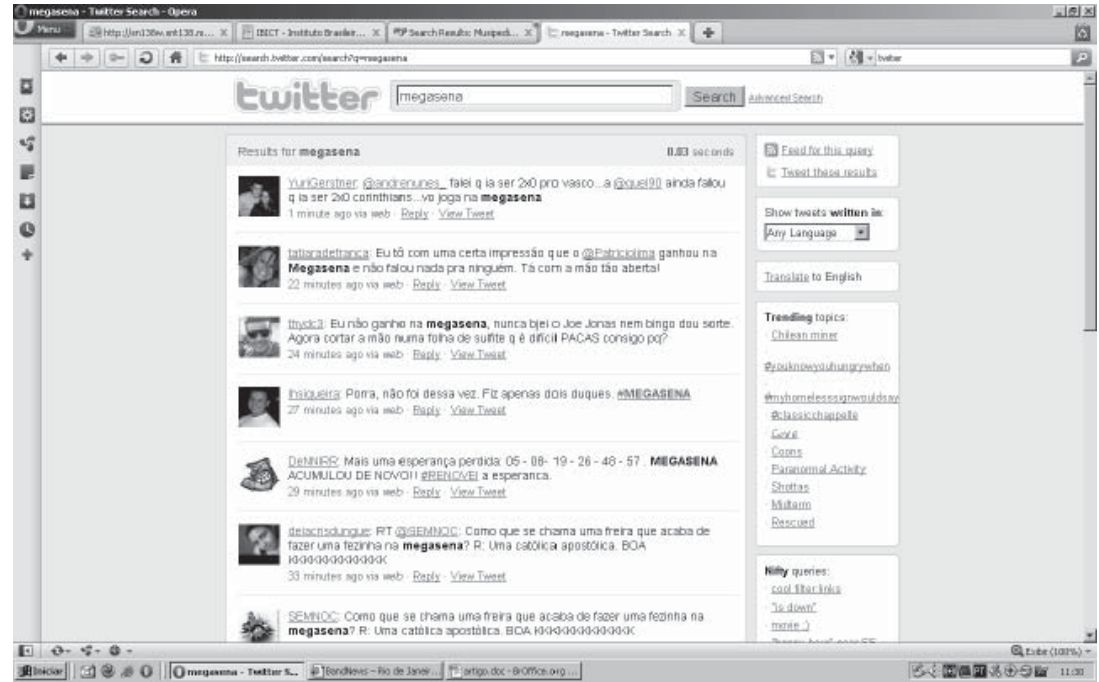


Não obstante, qualquer mecanismo de busca geral, ou especializado em blogs, pode ir ao encontro de poesias, consideradas, por Santaella (2005), o campo de virtualidades qualitativas da linguagem, portanto, outro exemplo da modalidade do discurso descritivo, que a autora classifica como quase não verbal, registro dos sentimentos, de qualidades.

No discurso narrativo o modo de expressão proeminente é o fato concreto, das experiências singulares. A lógica do discurso narrativo é o mundo que se move: da temporalidade das histórias ficcionais ou não, da locução de um jogo de futebol, o grau zero do acontecimento, no meio eletrônico, os blogs, diários de vidas comuns, com sua cronologia decrescente de registro de atualizações. Com efeito, os buscadores especializados em blogs, como o Google Glog (figura 7), contam e trazem a estatística dessa incrível audiência dos posts: narrativas virtuais.

Semelhante aos blogs, que se engendram no contexto das narrativas, o Twitter, por meio de seu mecanismo de busca, o Twitter Search (figura 8), está promovendo nova modalidade de busca, "a busca em tempo real", que está emergindo rapidamente no ciberespaço e chamando a atenção dos grandes serviços de busca. Por exemplo, pode-se encontrar resultados de busca no Twitter, com narrativas feitas e postadas há poucos segundos de diferença em relação ao momento da busca. Daí o nome busca em tempo real.

$\mathrm{Na}$ dissertação, como proeminência da linguagem verbal, o conceito opera abstrativamente a representação de seus discursos. Expressão do conhecimento, puramente intelectiva

\section{FIGURA 7}

FIGURA 8 e racional. Aqui é o território do signo genuíno de terceiridade fenomenológica. Pode-se situar o Google livros ou o Google Scholar (figura 9, a seguir) como exemplos típicos dessa modalidade.

Contudo, há ainda os mecanismos híbridos em que ocorrem processos de intersemiose, tal é o caso em que uma linguagem é utilizada para indexar e buscar produtos majoritariamente de outras linguagens, por exemplo, quando se utiliza o texto (linguagem verbal) para buscar música (linguagem sonora) e/ ou fotos (linguagem visual).

\section{Google Blog: pesquisa Google de blogs}

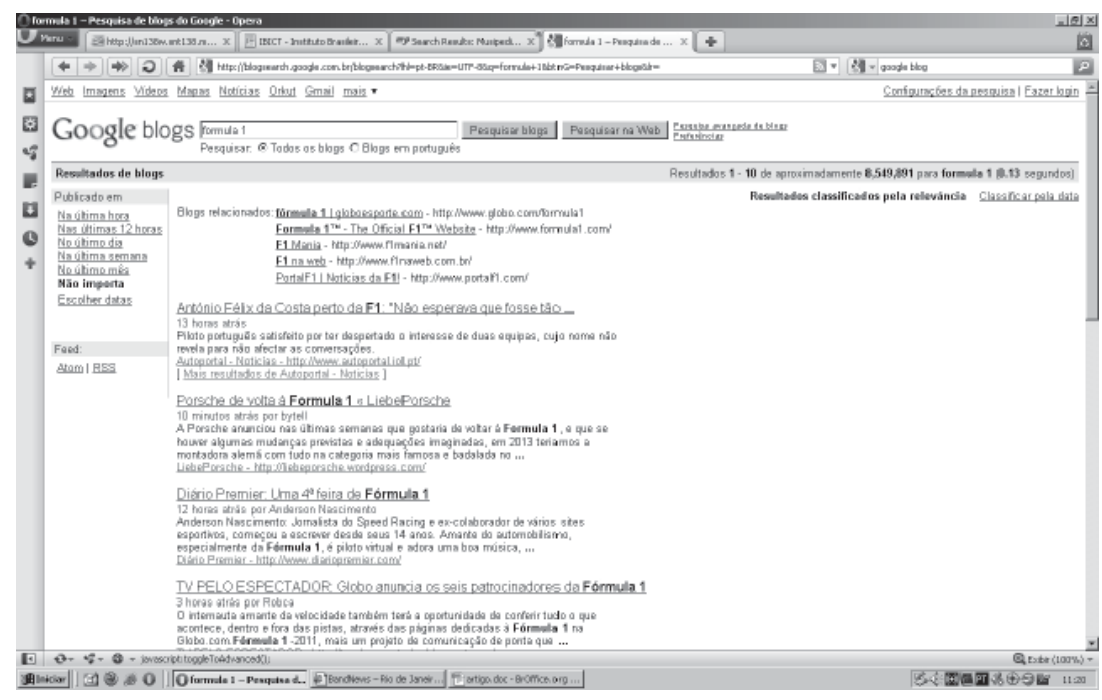

Twitter: The best way to discover what's new in your world

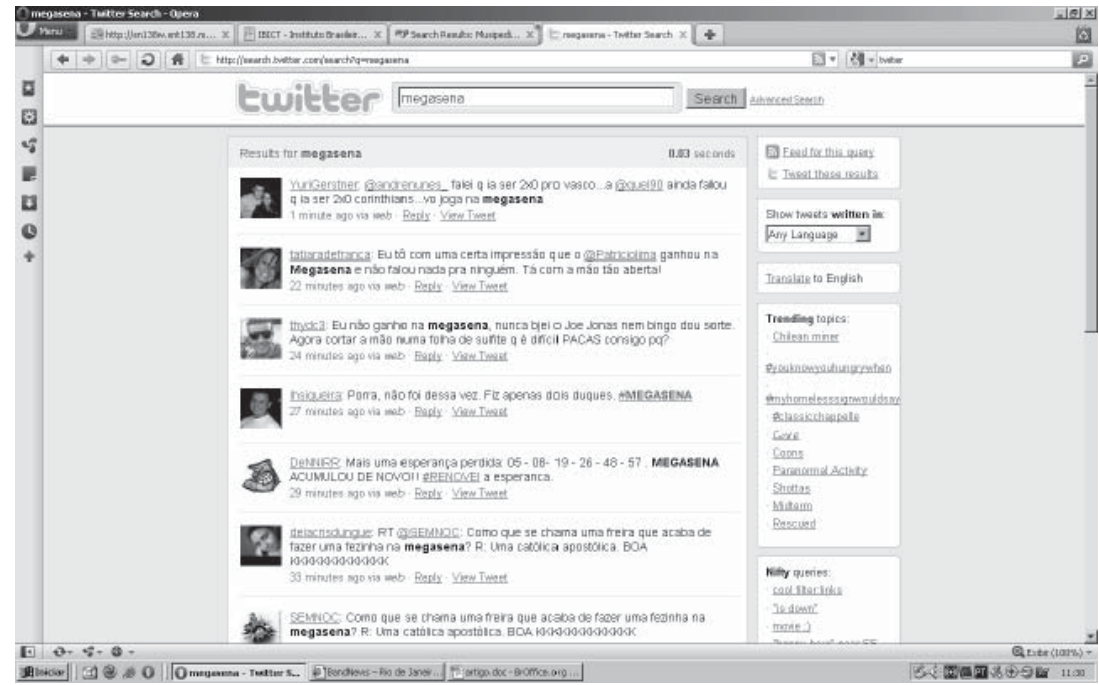


FIGURA 9

Goggle Scholar: sobre os ombros de gigantes

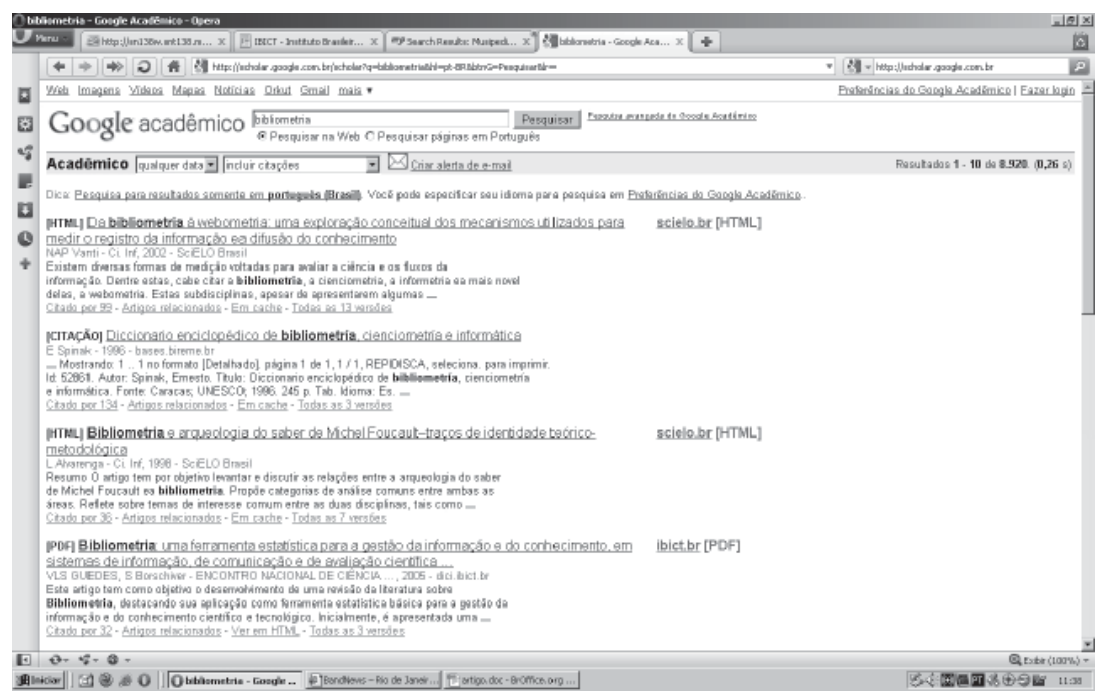

É comum encontrar mecanismos que oferecem caixas de busca em que se inserem palavras-chave para buscar fotos, músicas, vídeos, e dessa razão, pode-se deduzir que, se a caixa de busca é para entrada de palavras-chave, essas são semelhantes aos termos indexados. Nesse caso, os termos estão no lugar lógico de um documento que pode ser uma página Web, ou um arquivo de apresentação, entre outros. Por exemplo:

Fizy: permite ouvir música diretamente na página dos resultados de busca, sem a necessidade de se abrir a mídia de áudio em outro programa;

Blinkx: permite encontrar e assistir aos vídeos oriundos de diversas fontes em linha;

Yippy: um mecanismo de metabusca em que as páginas Web podem ser navegadas sem se sair da interface mesma do mecanismo.

\section{CONSIDERAÇÕES FINAIS}

Os mecanismos de busca, por estarem inseridos no contexto das tecnologias de informação e comunicação, são permanentemente acrescidas de novos aparatos tecnológicos e, por isso, encontramse em constante modificação. De modo que o estudo sobre as categorias dos mecanismos de busca deve ser contínuo, para que se acompanhem suas atualizações, as inovações, e se investiguem suas implicações para a área de ciência da informação.

Com isso, é razoável dizer que, a partir do ambiente virtual, ou seja, da virtualização das obras do conhecimento humano, outros paradigmas de indexação e busca emergiram no ciberespaço, níveis semióticos muito complexos, tal como apresentados neste estudo.

A compreensão do conceito agenciamento faz-se necessária para o entendimento da filosofia deleuzeana, que pressupõe fluxos semióticos de signos, quer sejam linguagens e fluxos materiais de corpos, quer sejam homens e máquinas (DELEUZE; GUATTARI, 1995).

Nesse sentido, especialmente a busca em si mesma, no ciberespaço, põe em conexão o sujeito cognoscente, denominado usuário, e a máquina, quaisquer sejam os mecanismos de busca. Logo, trata-se de agenciamentos maquínicos muito complexos, de modo que o objeto estudado foi ao mesmo tempo semiótico e material. E partindo desta perspectiva epistemológica que se realizou este estudo, com base na semiótica peirciana.

Em relação à interface de busca entre homens e máquinas, devem ser compreendidos todos os periféricos de entrada e saída da informação, ou seja, as caixas de som representam a interface sonora pela qual o usuário entra em contato com os resultados de músicas. E os microfones conectados ou embutidos nas máquinas são as interfaces que possibilitam ao usuário expressar suas intenções de busca em mecanismos de busca sonoros. E, assim por diante, nos diversos regimes de signos envolvidos na organização e busca virtuais em diferentes linguagens que compreendem os variados estoques informacionais maquínicos. 
Não havendo um nivelamento rígido de cognição humana e de semiose na mente e na máquina, supõese que, semioticamente, a busca a partir dos aspectos da visualidade é menos complexa que a busca a partir do som para o usuário final, por ele estar mais habituado às convenções das formas visuais, e por sua vez, que a busca por meio de palavra é mais fácil que as anteriores, em razão do poder de convencionalidade e representação do símbolo, bem como devido ao hábito que os usuários têm em manipular os signos simbólicos da linguagem verbal.

Em relação à indexação da música, verificou-se que os mecanismos estão sustentados nas bases teóricas e convencionais desse regime de signos. Ou seja, quando comparada à matriz sonora, é a modalidade sintaxes convencionais a que melhor corresponde a esses programas. Tanto é assim, que o mecanismo analisado, Musipedia, oferece buscas a partir do ritmo e da melodia. Essa última, tanto analisando a expressão sonora direta do usuário, ou por meio do código de Parson, que permite escrever o contorno melódico de uma obra musical graficamente.

A busca de modo análogo às formas visuais indica mecanismos específicos, tais como o Retrivr e o VizSeek, que possibilitam ao usuário de busca expressar um esboço, um traço, uma cor específica ou uma forma definida para utilizar-se desses modelos como expressão de busca. São esses caracteres e atributos que compõem os registros no índice de tempo de execução, utilizado pelos buscadores em resposta à consulta do usuário.

É coerente notar que a espacialidade e a forma no eixo da classificação das formas visuais mostram aspectos relevantes da operacionalidade e da lógica dos mecanismos visuais apresentados no corpus desta investigação.

De modo abrangente, pode-se observar que, se na linguagem sonora a sintaxe se engendra no tempo, no caso da linguagem visual, a forma, ou regras sintáticas pelas quais as formas de representação visual são organizadas, engendram-se mais prontamente no espaço.
Já os mecanismos de busca baseados em conteúdo verbal engendram-se no eixo do discurso e são os mais conhecidos do grande público de usuários de busca, pois se trata de buscadores que operam signos convencionais, com os quais os usuários estão habituados. O corpus analisado compreende os mecanismos de busca BuscaPé e Google, esse último em diferentes especificidades, como a busca epecializada em blogs e a busca especializada em publicações acadêmicas.

Semioticamente, os signos convencionais são denominados símbolos, principalmente representados por palavras, e neles existe sempre uma força viva que induz o interpretante desse signo. Essa força pode ser chamada de lei, ou regra, que governa indefinidamente fenômenos particulares. Por se trata de hábitos, os significados dos símbolos podem ser alterados com o tempo.

Com efeito, é razoável dizer que, com base na pesquisa realizada encontram-se operantes no ciberespaço três matrizes virtuais de organização e busca da informação e do conhecimento: a sonora, a visual e a verbal.

A partir do paradigma semiótico e da linguagem como critério de seleção e análise, é viável a categorização dos mecanismos de busca em três categorias primordiais, sendo a indexação e busca:

- baseadas em conteúdos sonoros;

- baseadas em conteúdos visuais;

- baseadas em conteúdos verbais.

Enfim, a sintaxe é a representação do sonoro, a forma é a representação do visível e o discurso é a representação do conhecimento em sua expressão verbal.

Finalizando, o estudo em tela não se encerra com este trabalho, pois o objeto, devido à sua dinâmica no ciberespaço, impõe constante monitoramento teórico e intelectual, para que se acompanhe compreensivamente o avanço sociotécnico dos produtos de informação e de conhecimento, nesse 
caso, os mecanismos de busca, pertinentes aos estudos da área de ciência da informação.

Artigo submetido em 31/07/2010 e aceito em 22/02/2011.

\section{AGRADECIMENTOS}

Aos órgãos de fomento que viabilizaram esta pesquisa: Conselho Nacional de Desenvolvimento Científico e Tecnológico (CNPq) e Fundação Araucária.

\section{REFERÊNCIAS}

A9.COM. Disponível em: <http://a9.com/>. Acesso em: 14 out. 2010 .

ABREU, J. G. de. Paradigma semiótico dos mecanismos de busca no ciberespaço. In: ENCONTRO ANUAL DE INICIAÇÃO CIENTÍFICA, 17., 19-22 nov. 2008, Foz do Iguaçu. Anais... Foz do Iguaçu: UNIOESTE, 2008. 1 CD-ROM.

ALVES, Alaôr Caffé. Lógica: pensamento formal e argumentação. 3.ed. São Paulo: Quartier Latin, 2003.

BARDIN, Laurence. Análise de conteúdo. Lisboa: Edições 70, 1997.

BARTHES, Roland. Elementos de Semiologia. São Paulo: Cultrix, 1997.

BUSCAPÉ. Disponível em: < www.buscape.com.br>. Acesso em: 8 fev. 2010.

BLINKX. Disponível em: < http://www.blinkx.com/>. Acesso em: 4 out. 2010.

FIZY. Disponível em: <http://fizy.com/>. Acesso em: 4 out. 2010.

GOODRUM, Abby A. Image Information Retrieval: an overview of current research. Informing Science, v.3, n.2, p. 63-67, 2000. Disponível em: <inform.nu/Articles/Vol3/v3n2p63-66.pdf>. Acesso em: 27 jun. 2008.

GOOGLE BLOG. Disponível em: < http://blogsearch.google. com/>. Acesso em: 08 fev. 2010.

GOOGLE EARTH. Disponível em: <http://earth.google.com/ intl/pt/>. Acesso em: 17 jul. 2007.

GOOGLE SCHOLAR. Disponível em: < http:/ / scholar.google.com. br/>. Acesso em: 08 fev. 2010.

MONTEIRO, S. D. As múltiplas sintaxes dos mecanismos de busca no ciberespaço. Informação \& Informação, v.14, p. 68-102, 2009. Número especial. Organização do conhecimento no ciberespaço Disponível em: <http://www.uel.br/revistas/uel/index.php/ informacao/article/view/2027/3223>. Acesso em: 15 abr. 2010.
A organização virtual do conbecimento no ciberespaço: os agenciamentos do sentido e do significado. 2002. 267 f. Tese (Doutorado em Comunicação e Semiótica) - Programa de PósGraduação em Comunicação e Semiótica, Pontifícia Universidade Católica de São Paulo, São Paulo, 2003.

MONTEIRO, S. D.; ABREU, J. G. de. O pós-moderno e a organização do conhecimento no ciberespaço: agenciamentos maquínicos. DataGramaZero, v.10, n.6, p. 1-7, dez. 2009. Disponível em: < http:// www.dgz.org.br/dez09/Art_05.htm>. Acesso em: 06 maio 2010.

Semiótica peirciana e a questão da informação e do conhecimento. Enc. Bibli: R. Eletr. Bibliotecon. Ci. Inf., Florianópolis, n. 2, 2. sem., p. 43-57, 2006. Número especial. Disponível em: <http:/ / www.periodicos.ufsc.br/index.php/eb/article/viewFile/369/433>. Acesso em: 17 abr. 2009

MUSIPEDIA: the open music encyclopedia. Disponível em: < http:/ / www.musipedia.org>. Acesso em: 13 jun. 2009.

PAGE, L.; BRIN. S. The anatomy off a large-scale hypertextual web search engine. In: INTERNATIONAL WORLD-WIDE WEB CONFERENCE, 7., Apr. 14-18, 1998, Brisbane, Australia. Proceedings... Brisbane: Stanford University, 1998. Disponível em: <http://infolab.stanford.edu/ backrub/google.html>. Acesso em: 12 out. 2010 .

RETRIEVR SYSTEMONE. Disponível em: <http://labs. systemone.at/retrievr/>. Acesso em: 19 jul. 2009.

REISS, J. D; SANDLER, M. B. Benchmarking Music Information Retrieval Systems. Disponível em: <www.music-ir.org/evaluation/wp1/ wp1_reiss.pdf $>$. Acesso em: 12 mar. 2008.

SANTAELLA, L. Matrizes da linguagem e pensamento: sonora, visual, verbal: aplicações na hipermídia. São Paulo: Iluminuras e FAPESP, 2005.

O que é semiótica. São Paulo: Melhoramentos, 1983.

A teoria geral dos signos: semiose e autogeração. São Paulo: Ática, 1995.

As três matrizes da linguagem-pensamento. Cult, São Paulo, p. 14-17, dez. 1999.

TWITTER. Disponível em: < http://twitter.com/>. Acesso em: 14 out. 2010 .

VIZSEEK. HotSpot \& VizSpace. Disponível em: < http://www. vizseek.com/vizspace/vizspace.aspx?uid=CADF11DF-3886-45799E77-22EDC465D7D3>. Acesso em: 22 jul. 2009.

YIPPY. Disponível em: < http://search.yippy.com/>. Acesso em: 4 out. 2010. 